Check for updates

Cite this: RSC Adv., 2017, 7, 31252

\title{
Fabrication and evaluation of a highly durable and reliable chloride monitoring sensor for civil infrastructure
}

\author{
Subbiah Karthick, ${ }^{\text {ab }}$ Seung-Jun Kwon, ${ }^{c}$ Han Seung Lee, ${ }^{\text {*a }}$ Srinivasan Muralidharan, ${ }^{d}$ \\ Velu Saraswathy (D) *ac and Rethinam Natarajan ${ }^{b}$
}

A solid-state alkaline stable polymer coated $\mathrm{Ag} / \mathrm{AgCl}$ sensor was fabricated for chloride sensing in concrete structures. The $\mathrm{Ag} / \mathrm{AgCl}$ sensor was fabricated by sintering the $\mathrm{AgCl}$ powder with $\mathrm{Ag}$ wire. Polypyrrole (PPy) was prepared by simple chemical synthesis. The unwavering character of the prepared PPy coated $\mathrm{Ag} / \mathrm{AgCl}$ sensor in saturated $\mathrm{KCl}$ solution was exemplified by potentiodynamic polarization studies followed by half-cell potential (HCP). The alkaline stability of the $\mathrm{Ag} / \mathrm{AgCl}$ and PPy coated $\mathrm{Ag} / \mathrm{AgCl}$ sensor in synthetic concrete pore solution (SCPS) was characterized by HCP, X-ray diffraction (XRD) and scanning electron microscopic (SEM) studies. The PPy coated chloride sensor was calibrated in saturated $\mathrm{KCl}$, distilled water and SCPS with various concentrations of chloride ions. The results showed a good relationship between the sensitivity of the sensor regarding the potential to the logarithm of chloride activity. Further, it was noticed that the potential value remained stable with increasing immersion time.

Received 17th May 2017

Accepted 8th June 2017

DOI: $10.1039 / c 7 r a 05532 c$

rsc.li/rsc-advances selective electrode. ${ }^{9-12}$ This technique seems to be a destructive, time-consuming process and requires periodic repetition and interpretation to obtain accurate data. Furthermore, destructive methods bring additional indirect cost due to road closures and traffic delays. ${ }^{\mathbf{1 3 , 1 4}}$ Hence, the civil and construction industries are searching for non-destructive techniques for chloride monitoring in concrete structures. The entire problem will be overcome by using embeddable sensors for continuous monitoring of chloride ion content, which is a simplified procedure and easily adaptable method..$^{15}$ In this regard, the $\mathrm{Ag} / \mathrm{AgCl}$ electrode is considered as one of the most commonly used sensors because it has a Nernstian response to the variations of chloride $\left(\mathrm{Cl}^{-}\right)$or silver $\left(\mathrm{Ag}^{+}\right)$activity and displays excellent sensitivity. ${ }^{\mathbf{1 6}} \mathrm{Ag} / \mathrm{AgCl}$ electrodes have become well established over the last decade and have been employed for analytical applications. ${ }^{17}$ Gurusami et al. reported the use of $\mathrm{Ag} / \mathrm{AgCl}$ sensors embedded in concrete as reference electrodes and good long-term results were collected over a period of about 4.5 years. ${ }^{16}$ The first attempt in concrete was made in the 1990s. Potentiometric measurement using an $\mathrm{Ag} / \mathrm{AgCl}$ electrode is the standard electrochemical technique to measure the free chloride in concrete. ${ }^{18-22}$ A study carried out using $\mathrm{Ag} / \mathrm{AgCl}$ for chloride monitoring in simulated concrete pore solutions revealed that at higher chloride concentration, $\mathrm{pH}$ has a significant influence on the potential value of the sensor. ${ }^{23} \mathrm{An} \mathrm{Ag} / \mathrm{AgCl}$ wire was employed as a sensor for determination of water soluble chlorides in admixtures and aggregates for cement. ${ }^{24}$ It was reported that, according to the Nernst law, the equilibrium 
potential value of the $\mathrm{Ag} / \mathrm{AgCl}$ electrode depends on the chloride ion activity (concentration) of the surrounding solution, and an $\mathrm{Ag} / \mathrm{AgCl}$ electrode can be used to determine the chloride activity in simulated cement pore solution, mortar and concrete samples. ${ }^{25,26}$

However, studies revealed that embeddable $\mathrm{Ag} / \mathrm{AgCl}$ electrodes in concrete are not stable for a long time, which is owing to the high alkalinity of the concrete. It was reported that in the $\mathrm{pH}$ range from 11.9 to 13.7 , low concentrations of chloride cannot be accurately determined by potentiometric measurements owing to the $\mathrm{OH}^{-}$interference. ${ }^{22,27}$ Besides, in the high alkaline solution and the presence of hydroxyl ions, silver activity near the surface is determined by exchange equilibrium, as shown in eqn (1): $:^{28}$

$$
2 \mathrm{AgCl}+2 \mathrm{OH}^{-} \rightarrow \mathrm{Ag}_{2} \mathrm{O}+2 \mathrm{Cl}^{-}+\mathrm{H}_{2} \mathrm{O}
$$

The AgCl membrane becomes unstable and is turned into $\mathrm{Ag}_{2} \mathrm{O}$ partly or wholly at high $\mathrm{pH}$ values. By the continuous transformation of the electrode surface into $\mathrm{Ag}_{2} \mathrm{O}$, a mixed potential is developed at the electrode/solution interface and it becomes incapable of accurately determining the free chloride content in the concrete structure. ${ }^{22}$ Therefore, to increase the stability of the $\mathrm{Ag} / \mathrm{AgCl}$ electrode and to reduce the $\mathrm{OH}^{-}$ion interference in the alkaline environment, the use of a conducting, alkaline stable conjugated polymer coating on an $\mathrm{Ag} / \mathrm{AgCl}$ electrode was reported..$^{28,29}$

In this aspect, a polypyrrole polymer matrix was used because it is one of the most frequently used polymers, can be readily synthesized, and it is more stable, lower cost, and has higher conductivity when compared to other polymers; it has been employed for many applications. ${ }^{30,31}$ Pickup et al. ${ }^{32}$ constructed a polypyrrole-mercury/mercury chloride coated glassy carbon electrode as a reference electrode. Mangold et al. $^{33}$ investigated a polypyrrole-silver/silver chloride as a reference electrode based on the surrounding electrolyte. The open circuit potential of this electrode strongly depends on the concentration of the supporting electrolyte. Furthermore, polypyrrole coated on a carbon electrode and polypyrrole incorporated on a metal electrode ( $\mathrm{Pt}, \mathrm{In}-\mathrm{SnO}_{2}$ and glassy carbon) was tried as a pH sensor, glucose sensor, and biosensor. PPy and PPy-based coatings have been proved to be very effective inhibitors in the corrosion of oxidizable metals and alloys, stainless steels, mild steel, etc. Besides these, PPy films are being used in other areas, such as in sensors and bio-fuel cells. ${ }^{34}$

To date, no in-depth studies have been carried out using an $\mathrm{Ag} / \mathrm{AgCl}$ electrode for in situ chloride sensing application in concrete structures. Hence, the present study aimed at developing a low cost, accurate and highly alkaline, long-term stable PPy coated Ag/AgCl solid electrode as an embeddable sensor for chloride sensing in concrete structures. The electrochemical stability of this PPy coated $\mathrm{Ag} / \mathrm{AgCl}$ electrode was evaluated in simulated concrete pore solutions with different chloride ion concentrations. The chloride sensitivity of the PPy coated solid electrode was assessed against an $\mathrm{MnO}_{2}$ solid sensor in chloride contaminated concrete by embedding the sensor at different depths.

\section{Materials and methods}

\subsection{Materials and methods}

The chemicals such as a silver wire $(\mathrm{Ag})$, silver chloride $(\mathrm{AgCl})$ powder, pyrrole, sodium dodecyl sulfate, iron(III) chloride hexahydrate, $\mathrm{NaOH}, \mathrm{KOH}, \mathrm{CaO}$ and $\mathrm{NaCl}$ used were of analytical reagent grade with sufficient purity and were purchased from reputed chemical suppliers.

2.1.1. Fabrication of $\mathbf{A g} / \mathbf{A g C l}$ electrode. Powders of silver and silver chloride in a $1: 1$ ratio were mixed and pressed into a pellet shape of $2 \mathrm{~mm}$ thick using a hydraulic pressing machine $(10 \mathrm{MPa})$, then sintered at a temperature of $400 \pm 10^{\circ} \mathrm{C}$ in a suitable ceramic sintering boat in $\mathrm{N}_{2}$ atmosphere. A suitable silver wire was used as an electrical lead and was embedded before the sintering operation to make the $\mathrm{Ag} / \mathrm{AgCl}$ pellet shape. The final size of the $\mathrm{Ag} / \mathrm{AgCl}$ electrode was around $10 \times 20 \mathrm{~mm}$ in a rectangle shape and it was found to be electronically conductive.

2.1.2. Preparation of polypyrrole (PPy). $0.86 \mathrm{~g}$ of sodium dodecyl sulfate was added to $30 \mathrm{~mL}$ of distilled water and then stirred moderately with a magnetic stirrer. The solution was agitated for $30 \mathrm{~min}$ at room temperature $\left(30 \pm 5{ }^{\circ} \mathrm{C}\right)$ until the surfactant was thoroughly dissolved. When a clear aqueous solution of surfactant was obtained, $1 \mathrm{~g}$ of pyrrole (monomer) was added dropwise to the solution with continuous stirring. After obtaining a mixture of aqueous surfactant and the pyrrole solution, an aqueous solution of $9.25 \mathrm{~g}$ of iron(III) chloride hexahydrate dissolved in $5 \mathrm{~mL}$ of distilled water was added dropwise to the mixture. The immediate formation of black PPy precipitate was clearly observed. ${ }^{35}$ The polymerization process was carried out for $2 \mathrm{~h}$ at room temperature with moderate stirring. The black polypyrrole precipitate was filtered off and washed with distilled water and then dried under vacuum at room temperature for $24 \mathrm{~h}$.

2.1.3. Polymer coating on Ag/AgCl electrode. PPy (90\%), carbon black (5\%), polyvinylidene fluoride (PVdF) (5\%) and $\mathrm{N}$ methyl-2-pyrrolidinone (NMP) as a solvent were mixed together to make a slurry. After that, the slurry was coated on the $\mathrm{Ag} / \mathrm{AgCl}$ electrode by dip coating technique. The electrode was dried at $80 \pm 10^{\circ} \mathrm{C}$ in a hot air oven for $12 \mathrm{~h}$ to remove the solvent.

\subsection{Testing in saturated $\mathrm{KCl}$}

2.2.1. Half-cell potential measurement. The half-cell potentials ( $\mathrm{HCP})$ of the fabricated bare $\mathrm{Ag} / \mathrm{AgCl}(\mathrm{Fb}-\mathrm{Ag} / \mathrm{AgCl})$ and $\mathrm{PPy}$ coated $\mathrm{Ag} / \mathrm{AgCl}(\mathrm{PPy}-\mathrm{Ag} / \mathrm{AgCl})$ electrodes were monitored in saturated potassium chloride solution (sat. $\mathrm{KCl}$ ) with respect to a saturated calomel electrode (SCE) for an exposure period of 30 days.

2.2.2. Potentiodynamic polarization studies. Potentiodynamic polarization studies were carried out for the $\mathrm{Fb}-\mathrm{Ag} / \mathrm{AgCl}$ electrode and the $\mathrm{PPy}-\mathrm{Ag} / \mathrm{AgCl}$ electrode, keeping them as the working electrode. A rectangular platinum foil was used as a counter electrode and SCE as a reference electrode. A saturated $\mathrm{KCl}$ solution was taken as a test solution in the polarization cell. The test solution was continuously stirred using a magnetic stirrer to avoid concentration polarization. Time 
Table 1 Chemical compositions of the ordinary Portland cement (OPC) used for the study

Chemical composition (mass\%)
Physical properties

Specific gravity

$\left(\mathrm{g} \mathrm{cm}^{-3}\right)$

3.16

Blaine $\left(\mathrm{cm}^{2} \mathrm{~g}^{-1}\right)$

\begin{tabular}{llllllllll} 
Components & $\mathrm{SiO}_{2}$ & $\mathrm{Al}_{2} \mathrm{O}_{3}$ & $\mathrm{Fe}_{2} \mathrm{O}_{3}$ & $\mathrm{CaO}$ & $\mathrm{MgO}$ & $\mathrm{SO}_{3}$ & $\mathrm{LOI}$ & $\left(\mathrm{g} \mathrm{cm}^{-3}\right)$ & $\mathrm{Blaine}\left(\mathrm{cm}^{2} \mathrm{~g}^{-1}\right)$ \\
\hline OPC & 21.96 & 5.27 & 3.44 & 63.41 & 2.13 & 1.96 & 0.79 & 3.16 & 3214
\end{tabular}

intervals of 30-45 min were given for maintaining the equilibrium of the system, and the HCP was noted. Both anodic and cathodic polarization curves were recorded potentiodynamically using an ACM Instruments, UK. The corrosion kinetic parameters such as $I_{\text {corr }}, E_{\text {corr }}, b_{\mathrm{a}}$ and $b_{\mathrm{c}}$ were measured with built-in software. The potentiodynamic polarization condition corresponds to a potential sweep rate of $1 \mathrm{mV} \mathrm{s}^{-1}$ and potential range of $-200 \mathrm{mV}$ to $+200 \mathrm{mV}$ from the HCP. All the experiments were carried out at a constant temperature of $30 \pm 5{ }^{\circ} \mathrm{C}$.

\subsection{Testing in various chloride concentrations}

The $\mathrm{Fb}-\mathrm{Ag} / \mathrm{AgCl}$ and $\mathrm{PPy}-\mathrm{Ag} / \mathrm{AgCl}$ electrodes were calibrated in aqueous $\mathrm{NaCl}$ solutions with different concentration of chloride ions from 0.001 mole per $\mathrm{L}$ to 1.0 mole per $\mathrm{L}$. The potentials developed by both electrodes were measured with respect to SCE. The $\mathrm{pH}$ of the test solution was observed as neutral. Further, the response of the $\mathrm{Fb}-\mathrm{Ag} / \mathrm{AgCl}$ and $\mathrm{PPy}-\mathrm{Ag} / \mathrm{AgCl}$ electrodes under alkaline environment was calibrated in synthetic concrete pore solution (SCPS) contaminated with chloride ions ranging from 0.001 mole per $\mathrm{L}$ to 1.0 mole per $\mathrm{L}$.

\subsection{Stability of $\mathbf{F b}-\mathrm{Ag} / \mathrm{AgCl}$ and $\mathrm{PPy}-\mathrm{Ag} / \mathrm{AgCl}$ electrodes in SCPS}

2.4.1. Half-cell potential. The synthetic concrete pore solution (SCPS) consists of $7.4 \mathrm{~g}$ of sodium hydroxide and $36.6 \mathrm{~g}$ of potassium hydroxide per litre of saturated calcium hydroxide solution. The $\mathrm{pH}$ of the solution was measured using a standard portable ISTEK pH meter (Model 76P) with a relative accuracy of \pm 0.001 . The $\mathrm{pH}$ of the SCPS was 13.5 . The potential stability of the $\mathrm{Fb}-\mathrm{Ag} / \mathrm{AgCl}$ and $\mathrm{PPy}-\mathrm{Ag} / \mathrm{AgCl}$ electrodes was studied by immersing the electrodes in SCPS representing a concrete environment for an exposure period of 60 days. The HCP developed by the $\mathrm{Fb}-\mathrm{Ag} / \mathrm{AgCl}$ and $\mathrm{PPy}-\mathrm{Ag} / \mathrm{AgCl}$ electrodes were measured in SCPS with respect to SCE for an exposure period of 60 days.

The changes in the physical appearance of the $\mathrm{Fb}-\mathrm{Ag} / \mathrm{Ag} \mathrm{Cl}$ and $\mathrm{PPy}-\mathrm{Ag} / \mathrm{AgCl}$ electrodes were monitored every day.

2.4.2. X-ray diffraction studies (XRD) and SEM analysis. Before and after immersion in SCPS for an exposure period of 60 days the $\mathrm{Fb}-\mathrm{Ag} / \mathrm{AgCl}$ and $\mathrm{PPy}-\mathrm{Ag} / \mathrm{AgCl}$ electrodes were subjected to XRD studies. A computer controlled XRD system (JEOL, JPX8030) with Cu$\alpha \mathrm{K}$ radiation (Ni filter $=13418 \AA$ ) in the range of $40 \mathrm{kV}, 20 \mathrm{~A}$ was used for the recording of XRD patterns.

Scanning electron microscopy (SEM) images were obtained using a Hitachi Model $\mathrm{S}-3000 \mathrm{H}$ at various magnifications to study the surface morphology of the $\mathrm{Fb}-\mathrm{Ag} / \mathrm{AgCl}$ and $\mathrm{PPy}-\mathrm{Ag} /$
AgCl electrodes before and after immersion in SCPS for the period of 60 days.

\subsection{Potential measurement in various solutions}

The PPy-Ag/AgCl electrode was dipped in different solutions such as distilled water and SCPS with various chloride concentrations ( 0.25 mole per L, 0.50 mole per L and 1.0 mole per L). The potential developed by this electrode was measured with respect to SCE. The $\mathrm{pH}$ of the test solutions was varied from 11 to 13.5. The potential values noted at different time durations were plotted as a graph. The reversibility behavior of $\mathrm{PPy}-\mathrm{Ag} / \mathrm{AgCl}$ electrode in low and high concentrations of chloride ion was also measured.

\subsection{Electrochemical studies}

The procedure mentioned in the Experimental section 2.2.2 was followed for carrying electrochemical studies, and here the working electrode taken was the $\mathrm{PPy}-\mathrm{Ag} / \mathrm{AgCl}$ electrode and the electrolyte used was SCPS and SCPS with chloride ion concentrations of 0.25 mole per L, 0.50 mole per L and 1.0 mole per L.

The same three electrode setup was used for AC-impedance measurement. The AC-impedance measurement for the PPy$\mathrm{Ag} / \mathrm{AgCl}$ electrode was carried out using an ACM Instruments (UK) field machine with a frequency range of $30 \mathrm{kHz}$ to $10 \mathrm{mHz}$ and an amplitude of $20 \mathrm{mV}$. Nyquist plots were recorded for all the systems studied and are presented in graph form.

\subsection{Evaluation of the PPy-Ag/AgCl electrode embedded in concrete for chloride ion sensitivity}

A concrete cube with dimensions of $150 \mathrm{~mm} \times 150 \mathrm{~mm} \times 150$ mm was cast using a $1: 1.80: 3.696$ mix ratio of cement : fine aggregate : coarse aggregate containing a 0.55 water/cement ratio. The chemical composition of ordinary Portland cement (OPC) used is given in Table 1. Clean river sand passing through a $2.36 \mathrm{~mm}$ sieve and falling under zone III with a specific gravity 2.60 was used as a fine aggregate. The coarse aggregates used were crushed stone aggregates with a normal size of $19 \mathrm{~mm}$ and a specific gravity of 2.6. The $\mathrm{PPy}-\mathrm{Ag} / \mathrm{AgCl}$ electrodes were embedded in concrete at various depths of 5, 10, 20, 30 and 40 mm (Fig. 1) along with the $\mathrm{MnO}_{2}$ solid state reference electrode (SSRE), which was embedded very close to the $\mathrm{PPy}-\mathrm{Ag} / \mathrm{AgCl}$ electrode. After $24 \mathrm{~h}$, the concrete specimens were demolded and cured for 28 days in distilled water. After curing, the concrete cubes were dried and all the four faces of the concrete cubes were sealed with epoxy, except the top and bottom surface for subjecting to the flow of chloride ions from the top surface, 

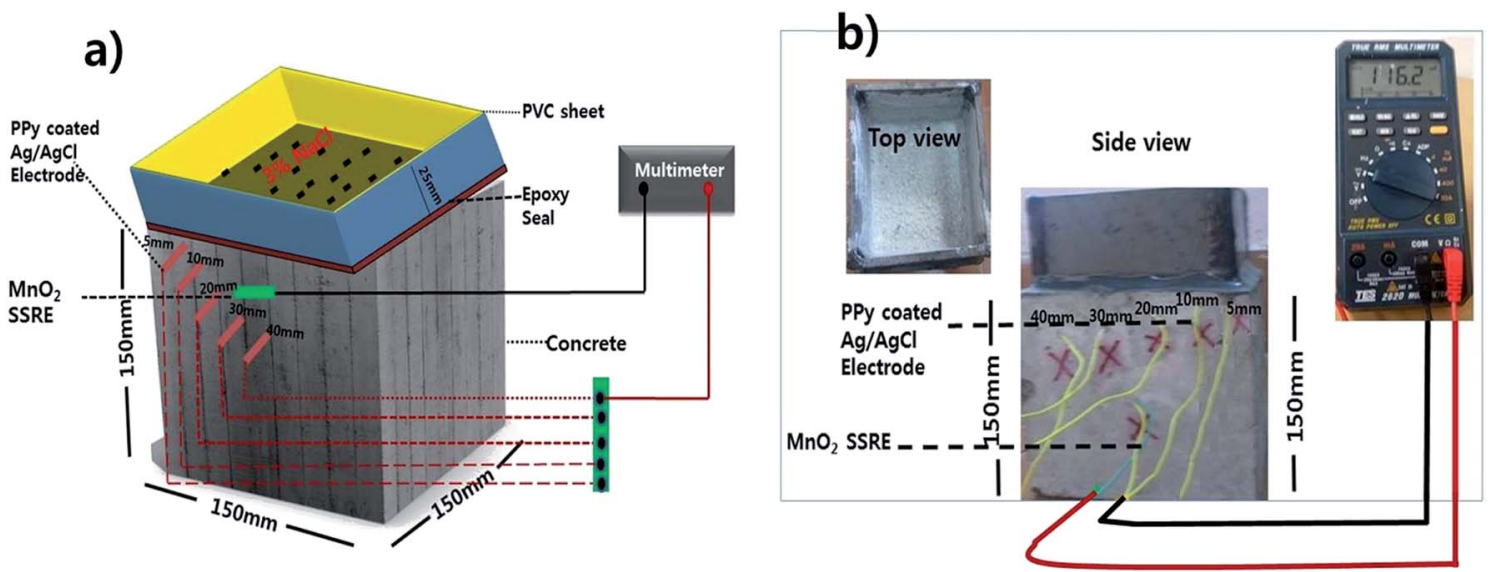

Fig. $1 \mathrm{PPy}-\mathrm{Ag} / \mathrm{AgCl}$ electrodes embedded at various depths $(5,10,20,30,40 \mathrm{~mm})$ along with $\mathrm{MnO}_{2}$ in concrete exposed to $3 \%$ chloride environment.

as shown in Fig. 1a. The top surface of the cube was surrounded with a PVC mold and glued to the sides of the concrete to prevent solution leakage. Then $3 \% \mathrm{NaCl}$ solution was poured onto the top surface of the concrete and allowed to penetrate over a period of 90 days at room temperature. In this process, alternate wet and dry cycles were performed to accelerate the corrosion process. One cycle consists of 3 days wetting in chloride solution and 3 days drying in an open atmosphere at room temperature. The potential readings were taken during the $3^{\text {rd }}$ day of wetting, after wiping the solution out. The experimental setup for carrying out the measurements is shown in Fig. $1 b$.

\section{Results and discussion}

\subsection{Properties of $\mathbf{A g} / \mathbf{A g C l}$ electrode}

The $\mathrm{Ag} / \mathrm{AgCl}$ electrodes prepared by sintering process were rugged and electronically conductive. The polypyrrole solution

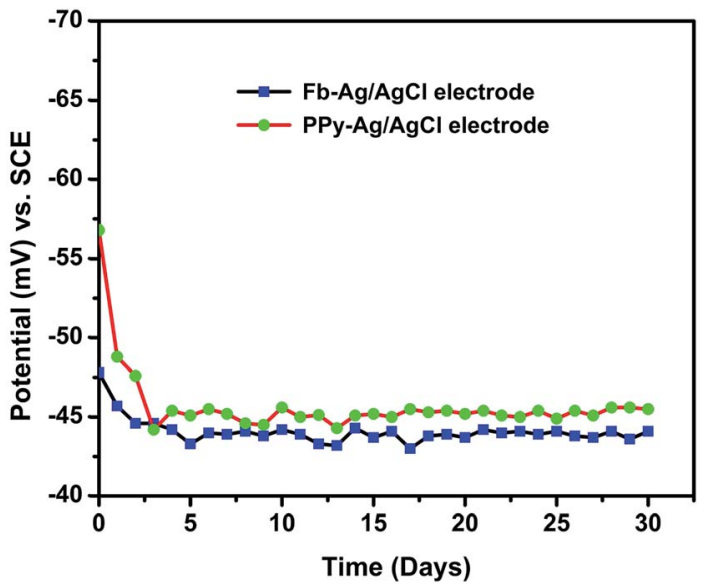

Fig. 2 Potential stability of the $\mathrm{Fb}-\mathrm{Ag} / \mathrm{AgCl}$ and $\mathrm{PPy}-\mathrm{Ag} / \mathrm{AgCl}$ electrodes in saturated $\mathrm{KCl}$ solution. prepared makes a thixotropic slurry along with NMP and PVDF and no trace of NMP was found after drying at $80 \pm 10^{\circ} \mathrm{C}$.

\subsection{Testing in sat. $\mathrm{KCl}$}

3.2.1. Half-cell potential measurement. The uniformity of the electrode was assured by testing the stability of the PPy-Ag/ $\mathrm{AgCl}$ electrode in sat. $\mathrm{KCl}$ for an exposure period of 30 days with respect to SCE and comparing it with $\mathrm{Fb}-\mathrm{Ag} / \mathrm{AgCl}$. The potential vs. time behavior of the $\mathrm{Fb}-\mathrm{Ag} / \mathrm{AgCl}$ and $\mathrm{PPy}-\mathrm{Ag} / \mathrm{AgCl}$ electrodes is given in Fig. 2. From the figure, it was found that the average $\mathrm{HCP}$ of $\mathrm{Fb}-\mathrm{Ag} / \mathrm{AgCl}$ and $\mathrm{PPy}-\mathrm{Ag} / \mathrm{AgCl}$ was $-44.08 \pm 2 \mathrm{mV}$ and $-46.04 \pm 2 \mathrm{mV}$, respectively, over an exposure period of 30 days. The potential difference between the $\mathrm{Fb}-\mathrm{Ag} / \mathrm{AgCl}$ and $\mathrm{PPy}-\mathrm{Ag} /$ $\mathrm{AgCl}$ electrodes was $+2.04 \pm 2 \mathrm{mV}$. This is due to the low resistance and improved adherence of the electrode/PPy contact region. ${ }^{36-39}$ This minor potential difference will not make any significant change to the $\mathrm{PPy}-\mathrm{Ag} / \mathrm{AgCl}$ electrode properties. From the figure, during the initial exposure period the potential fluctuation was observed owing to the incubation period for stabilizing the potential of electrode or owing to the reactions occurring at the $\mathrm{Ag} / \mathrm{AgCl} / \mathrm{PPy} /$ solution interface.

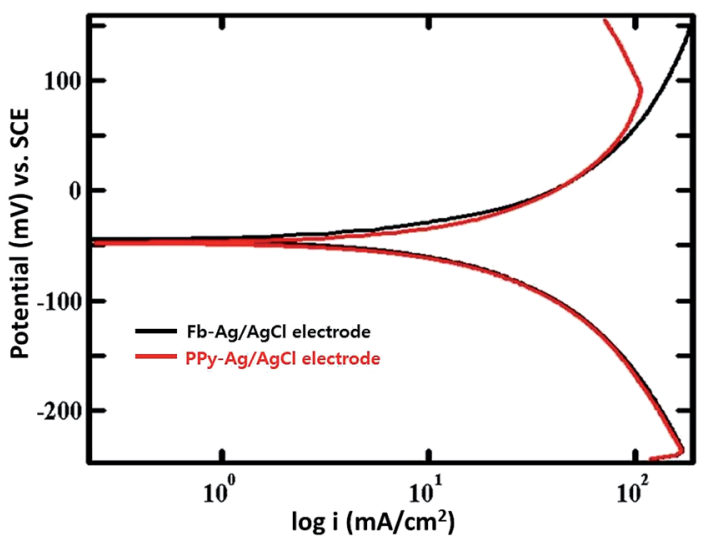

Fig. 3 Potentiodynamic polarization curves for the $\mathrm{Fb}-\mathrm{Ag} / \mathrm{AgCl}$ and $\mathrm{PPy}-\mathrm{Ag} / \mathrm{AgCl}$ electrodes in saturated $\mathrm{KCl}$ solution. 
Table 2 Potentiodynamic polarization parameters for the $\mathrm{Ag} / \mathrm{AgCl}$ and PPy coated electrodes in saturated $\mathrm{KCl}$ solution

\begin{tabular}{llllll}
\hline System & $R_{\mathrm{P}}(\mathrm{mV})$ & $E_{\text {corr }}(\mathrm{mV})$ & $b_{\mathrm{a}}\left(\mathrm{mV} \mathrm{dec}^{-1}\right)$ & $b_{\mathrm{c}}\left(\mathrm{mV} \mathrm{dec}^{-1}\right)$ & 41 \\
\hline Ag/AgCl & -44.03 & -44.8 & 40 & $4 I_{\text {corr }}\left(\mathrm{mA} \mathrm{cm}^{-2}\right)$ \\
PPy coated Ag/AgCl & -46.5 & -46.4 & 40 & 42 & 4.147
\end{tabular}

3.2.2. Potentiodynamic polarization studies. Fig. 3 shows the potentiodynamic polarization curves for the $\mathrm{Fb}-\mathrm{Ag} / \mathrm{AgCl}$ and $\mathrm{PPy}-\mathrm{Ag} / \mathrm{AgCl}$ electrodes in sat. $\mathrm{KCl}$ solution. The corrosion kinetic parameters derived from the Tafel plots are presented in Table 2. Here, as expected, the corrosion kinetic parameters for both electrodes were observed to be similar. For example, the $E_{\text {corr }}$ values of the $\mathrm{Fb}-\mathrm{Ag} / \mathrm{AgCl}$ and $\mathrm{PPy}-\mathrm{Ag} / \mathrm{AgCl}$ electrodes were found to be $-44.8 \pm 2 \mathrm{mV}$ and $-46.4 \pm 2 \mathrm{mV} v s$. SCE, respectively. Similarly, the $I_{\text {corr }}$ values of the $\mathrm{Fb}-\mathrm{Ag} / \mathrm{AgCl}$ and $\mathrm{PPy}-\mathrm{Ag} /$ $\mathrm{AgCl}$ electrodes were 4.147 and $4.126 \mathrm{~mA} \mathrm{~cm}^{-2}$, respectively. It was concluded that the application of a thin PPy coating on the $\mathrm{Ag} / \mathrm{AgCl}$ electrode did not affect the electrochemical behavior of the $\mathrm{Ag} / \mathrm{AgCl}$ electrode.

From the HCP measurement and potentiodynamic polarization studies, it was confirmed that PPy conducting polymers has been used as the immobilizing polymer matrix, ${ }^{\mathbf{4 0 , 4 1}}$ which facilitates the transfer of charge between the electrode and the active solution (sat. $\mathrm{KCl}){ }^{42}$

\subsection{Testing in various chloride concentrations}

Both the $\mathrm{Fb}-\mathrm{Ag} / \mathrm{AgCl}$ and $\mathrm{PPy}-\mathrm{Ag} / \mathrm{AgCl}$ electrodes were calibrated in different chloride concentrations to ensure the chloride sensing ability. The potentials measured with respect to SCE are plotted against various chloride concentrations ranging from 0.001 mole per L to 1.0 mole per L in Fig. 4. It was observed from Fig. 4 that both the electrodes showed similar behavior and different potentials were observed for different concentrations. Further, the measured potential decreases with increasing concentration of chloride. The chloride ion concentration decreases with the increase in potential, indicating that both the electrodes follow the Nernstian equation.

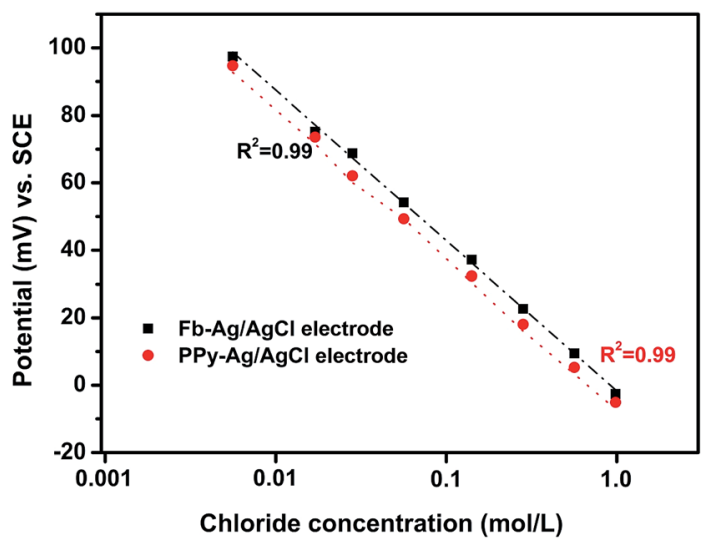

Fig. 4 Half-cell potential of the $\mathrm{Fb}-\mathrm{Ag} / \mathrm{AgCl}$ and $\mathrm{PPy}-\mathrm{Ag} / \mathrm{AgCl}$ electrodes in various chloride concentrations.

$$
E=E^{\mathrm{o}}-\frac{2.303 R T}{n F} \log [\mathrm{Cl}]^{-}
$$

Furthermore, the $\mathrm{Fb}-\mathrm{Ag} / \mathrm{AgCl}$ and $\mathrm{PPy}-\mathrm{Ag} / \mathrm{AgCl}$ electrodes calibrated in different chloride concentrations revealed a linear response with a correlation coefficient of 0.99 . Hence, the result indicates that both electrodes have good sensitive behavior at different chloride ion concentrations.

Fig. 5 shows the calibration of the $\mathrm{Fb}-\mathrm{Ag} / \mathrm{AgCl}$ and $\mathrm{PPy}-\mathrm{Ag} /$ $\mathrm{AgCl}$ electrodes under alkaline environment in synthetic concrete pore solution contaminated with chloride ions ranging from 0.001 mole per L to 1.0 mole per L. From the figure, it was found that $\mathrm{Fb}-\mathrm{Ag} / \mathrm{AgCl}$ electrode potential shows a uniform variation in the higher chloride concentration region $(0.01$ mole per L to 1.0 mole per L), forming a linear curve fit. At the same time, in the low concentration region ( 0.001 to 0.01 mole per $\mathrm{L}$ ) $\mathrm{Fb}-\mathrm{Ag} / \mathrm{AgCl}$ electrode potential was slightly variable from the linear curve, which may be due to the interference of $\mathrm{OH}^{-}$ ions, ${ }^{17}$ and this deviation could be attributed to the formation of $\mathrm{AgOH} .{ }^{15}$ On the other hand, the $\mathrm{PPy}-\mathrm{Ag} / \mathrm{AgCl}$ electrode showed a uniform variation in potential at all the chloride ion concentrations. However, the potential value of the $\mathrm{PPy}-\mathrm{Ag} / \mathrm{AgCl}$ electrode was slightly changed at lower concentrations of chloride ions due to the higher concentration of $\mathrm{OH}^{-}$interference during the measurement. This potential deviation is very low when compared to the $\mathrm{Fb}-\mathrm{Ag} / \mathrm{AgCl}$ electrode. This minor deviation is considered as a negligible change. Hence, the straight line curve of the $\mathrm{PPy}-\mathrm{Ag} / \mathrm{AgCl}$ electrode is exhibited at all chloride ion concentrations in Fig. 5. Moreover, the $\mathrm{PPy}-\mathrm{Ag} / \mathrm{AgCl}$ electrode showed a good linear response with a correlation coefficient of 0.98. It is slightly higher than that of the Fb-Ag/ $\mathrm{AgCl}$ electrode (0.94). Hence, a $\mathrm{PPy}-\mathrm{Ag} / \mathrm{AgCl}$ electrode has

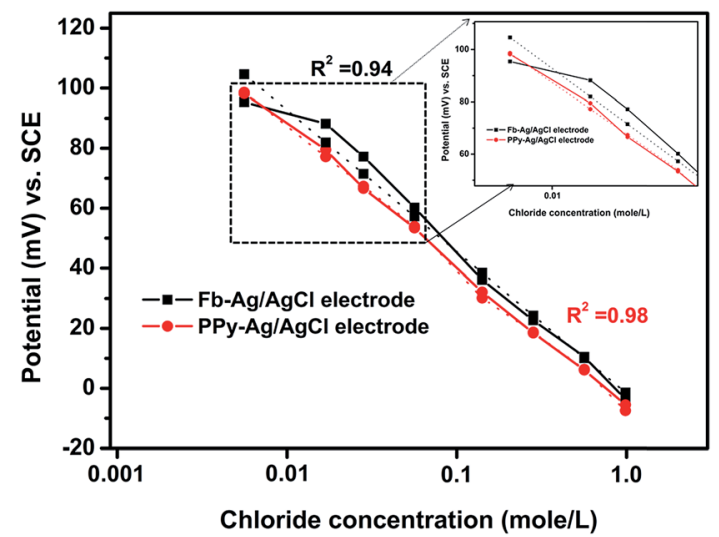

Fig. 5 Half-cell potential of the $\mathrm{Fb}-\mathrm{Ag} / \mathrm{AgCl}$ and $\mathrm{PPy}-\mathrm{Ag} / \mathrm{AgCl}$ electrodes in SCPS containing various chloride concentrations. 


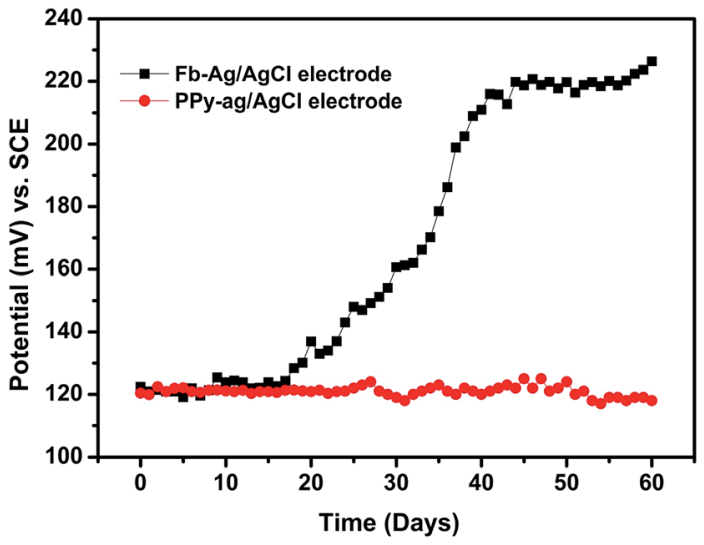

Fig. 6 Stability of the $\mathrm{Fb}-\mathrm{AgCl}$ and PPy- $\mathrm{Ag} / \mathrm{AgCl}$ electrodes in SCPS.

good sensible behavior and exhibits good Nernstian behavior in the high alkaline environment with low and high concentrations of chloride ions. Hence, the PPy electrode is stable in alkaline medium. ${ }^{39,43}$

\subsection{Stability of $\mathrm{Fb}-\mathrm{Ag} / \mathrm{AgCl}$ and $\mathrm{PPy}$ coated $\mathrm{Ag} / \mathrm{AgCl}$ electrodes in SCPS}

3.4.1. HCP measurements. The electrochemical potential stability of the $\mathrm{Fb}-\mathrm{Ag} / \mathrm{AgCl}$ and $\mathrm{PPy}-\mathrm{Ag} / \mathrm{AgCl}$ electrodes in SCPS was monitored by HCP measurement method for the exposure period of 60 days. Fig. 6 shows the potential-time behavior of the $\mathrm{Fb}-\mathrm{Ag} / \mathrm{AgCl}$ and $\mathrm{PPy}-\mathrm{Ag} / \mathrm{AgCl}$ electrodes in SCPS. It was observed from Fig. 6 that both the electrodes showed stable potential $(121 \pm 2 \mathrm{mV}$ and $119 \pm 2 \mathrm{mV})$ at the initial exposure period. After that the $\mathrm{Fb}-\mathrm{Ag} / \mathrm{AgCl}$ electrode does not display stable potential and a larger deviation was noticed after 17 days of exposure. The potential of the $\mathrm{Fb}-\mathrm{Ag} / \mathrm{AgCl}$ electrode was increasing and these deviations could be attributed to the formation of $\mathrm{AgOH}$ on the $\mathrm{Ag} / \mathrm{AgCl}$ electrode surface. After 45 days, the $\mathrm{Fb}-\mathrm{Ag} / \mathrm{AgCl}$ electrode showed a stable potential of +223 $\pm 2 \mathrm{mV}$. This potential value could be attributed to the complete formation of $\mathrm{Ag}_{2} \mathrm{O}$ on the $\mathrm{Fb}-\mathrm{Ag} / \mathrm{AgCl}$ electrode surface. ${ }^{44}$ The $\mathrm{AgCl}$ surface is easily oxidized in alkaline environment and the



Fig. 7 Pourbaix diagram of silver (Ag) metal.
AgCl reacts spontaneously with the $\mathrm{OH}^{-}$ions in the SCPS to form $\mathrm{AgOH}$ and $\mathrm{Ag}_{2} \mathrm{O}$ at the $\mathrm{AgCl}$ surface/solution interface. Based on this, the Pourbaix (potential vs. $\mathrm{pH}$ ) diagram of the $\mathrm{Ag}$ is schematically illustrated in Fig. $7 .^{45}$ In addition, the Pourbaix diagram is often used as the possible representation of the chemical and electrochemical reaction of $\mathrm{Ag}$ in alkaline solution. $^{\mathbf{4 6 , 4 7}}$ The probable chemical reaction of the $\mathrm{Ag} / \mathrm{AgCl}$ electrode in an alkaline medium is as follows.

$$
\begin{gathered}
\mathrm{AgCl}+\mathrm{OH}^{-} \rightarrow \mathrm{AgOH}+\mathrm{Cl}^{-} \\
2 \mathrm{AgOH} \rightarrow \mathrm{Ag}_{2} \mathrm{O}+\mathrm{H}_{2} \mathrm{O}
\end{gathered}
$$

Hence, the above reaction confirmed the formation of $\mathrm{Ag}_{2} \mathrm{O}$ at the $\mathrm{AgCl}$ surface/solution interface, so that the electrode potential of the $\mathrm{Fb}-\mathrm{Ag} / \mathrm{AgCl}$ electrode was unstable in SCPS. For our purpose, we need a stable $\mathrm{Ag} / \mathrm{AgCl}$ electrode in alkaline cement concrete for sensing the chloride ion concentration. This necessitates the coating on the $\mathrm{Ag} / \mathrm{AgCl}$ surface, especially for application in concrete structures. On the other hand, the PPy coated electrode developed a constant potential throughout the exposure period of 60 days. This because the PPy coating prevents the formation of $\mathrm{Ag}_{2} \mathrm{O}$ at the $\mathrm{AgCl}$ surface/solution interface. Therefore, the $\mathrm{OH}^{-}$ions interference was reduced in the $\mathrm{PPy}-\mathrm{Ag} / \mathrm{AgCl}$ electrode and then the electrochemical behavior of the PPy coated electrode is more stable in alkaline medium..$^{39,43}$

The photographic images captured during this experiment are given in Fig. 8. It can be clearly observed from Fig. 8 that after 19 days of exposure in SCPS the $\mathrm{Fb}-\mathrm{Ag} / \mathrm{AgCl}$ electrode has changed to brown color owing to the formation of $\mathrm{AgOH}$ at the $\mathrm{AgCl} /$ solution interface. The color change is also progressive owing to the rate of reaction between $\mathrm{AgCl}$ and $\mathrm{OH}^{-}$. The appearance of the black color after 60 days of exposure in alkaline solution may be due to the formation of $\mathrm{Ag}_{2} \mathrm{O}$ and hence showed their mixed potential of $\mathrm{Ag}_{2} \mathrm{O}$ and $\mathrm{AgCl}$ in Fig. 6. On the other hand, no color change was observed in the case of the PPy-Ag/AgCl electrode after 60 days of exposure in SCPS. It

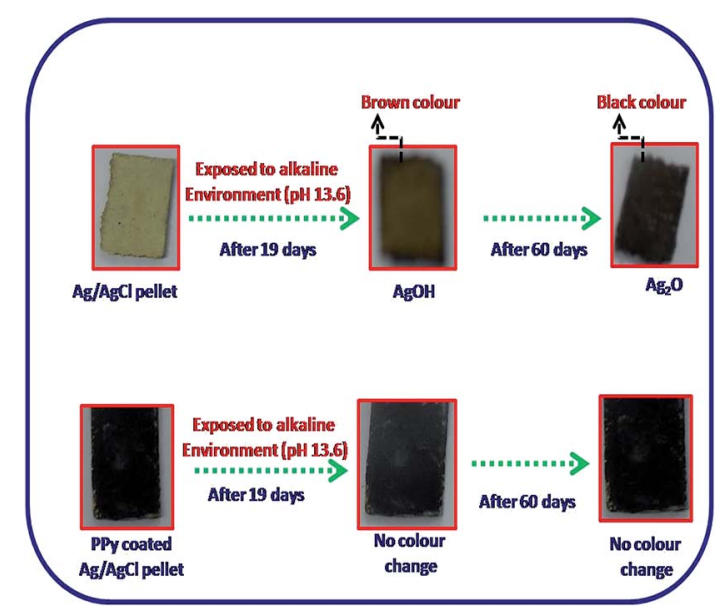

Fig. 8 Images of $\mathrm{Fb}-\mathrm{Ag} / \mathrm{AgCl}$ and $\mathrm{PPy}-\mathrm{Ag} / \mathrm{AgCl}$ electrodes before and after immersion in SCPS. 

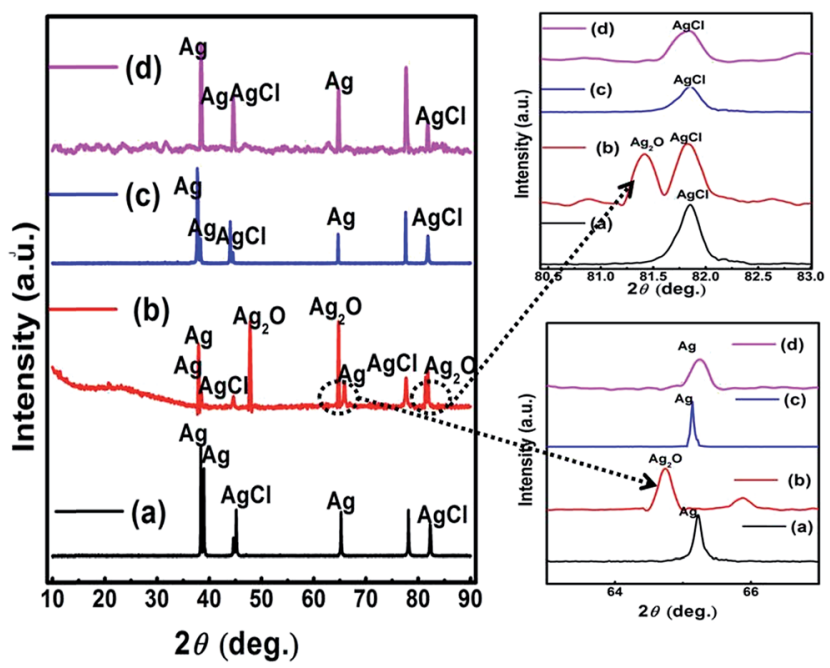

Fig. 9 XRD pattern of $\mathrm{Fb}-\mathrm{Ag} / \mathrm{AgCl}(\mathrm{a})$ and $\mathrm{PPy}-\mathrm{Ag} / \mathrm{AgCl}$ (c) electrodes before immersion in SCPS; $\mathrm{Fb}-\mathrm{Ag} / \mathrm{AgCl}$ (b) and $\mathrm{PPy}-\mathrm{Ag} / \mathrm{AgCl}$ (d) electrodes after immersion in SCPS.

is observed that the $\mathrm{PPy}-\mathrm{Ag} / \mathrm{AgCl}$ electrode in SCPS showed stable potential (Fig. 6) even after 60 days of exposure. This is quite suited for our interest to assemble an embeddable PPy-
$\mathrm{Ag} / \mathrm{AgCl}$ electrode for sensing the chloride ion concentration in concrete structures.

3.4.2. X-ray diffraction studies (XRD) and SEM analysis. Fig. 9 shows the XRD patterns of the $\mathrm{Fb}-\mathrm{Ag} / \mathrm{AgCl}$ electrode and the PPy- $\mathrm{Ag} / \mathrm{AgCl}$ electrode before and after exposure in SCPS for 60 days. Fig. 9a shows the XRD pattern of the $\mathrm{Fb}-\mathrm{Ag} / \mathrm{AgCl}$ electrode with salient peaks and Fig. $9 \mathrm{~b}$ shows the same $\mathrm{Fb}-\mathrm{Ag} / \mathrm{AgCl}$ electrode after immersion in SCPS further showing the peaks of $\mathrm{Ag}_{2} \mathrm{O}$ formation. When the $\mathrm{PPy}-\mathrm{Ag} / \mathrm{AgCl}$ electrode was exposed in SCPS, there was no appearance of peaks for $\mathrm{Ag}_{2} \mathrm{O}$. This is clearly indicated in Fig. 9d. Both Fig. $9 \mathrm{c}$ and d show similar peaks owing to the presence of the PPy film, which protected $\mathrm{AgCl}$ from the formation of $\mathrm{Ag}_{2} \mathrm{O}$. Fig. 9a and b indicate the $\mathrm{Ag}$ and $\mathrm{AgCl}$ peaks $(2 \theta)$ at $38.3^{\circ}, 44.6^{\circ}$ and $64.8^{\circ}$ and are attributed to the (111), (200), and (311) reflection planes, respectively, for cubic Ag (JCPDS no. 65-2871). The clear AgCl peaks at $45.2^{\circ}$, $76.7^{\circ}$ and $85.6^{\circ}$ are attributed to (220), (420) and (422), respectively, of the cubic phase of AgCl crystal (JCPDS no. 31-1238). Fig. $9 \mathrm{~b}$ shows the $\mathrm{Fb}-\mathrm{Ag} / \mathrm{AgCl}$ electrode that was exposed to the SCPS (pH of 13.6). A significant decrease in the intensity of peaks was observed for $\mathrm{Ag}$ and $\mathrm{AgCl}$ to form new high intensity peaks at $46.7^{\circ}, 64.9^{\circ}$ and $80.7^{\circ}$ assigned to (211), (311) and (400), respectively, of the cubic phase of $\mathrm{Ag}_{2} \mathrm{O}$ (JCPDS no. 76-1393). This $\mathrm{Ag}_{2} \mathrm{O}$ formation is the reason for the change in the $\mathrm{Fb}-\mathrm{AgCl}$
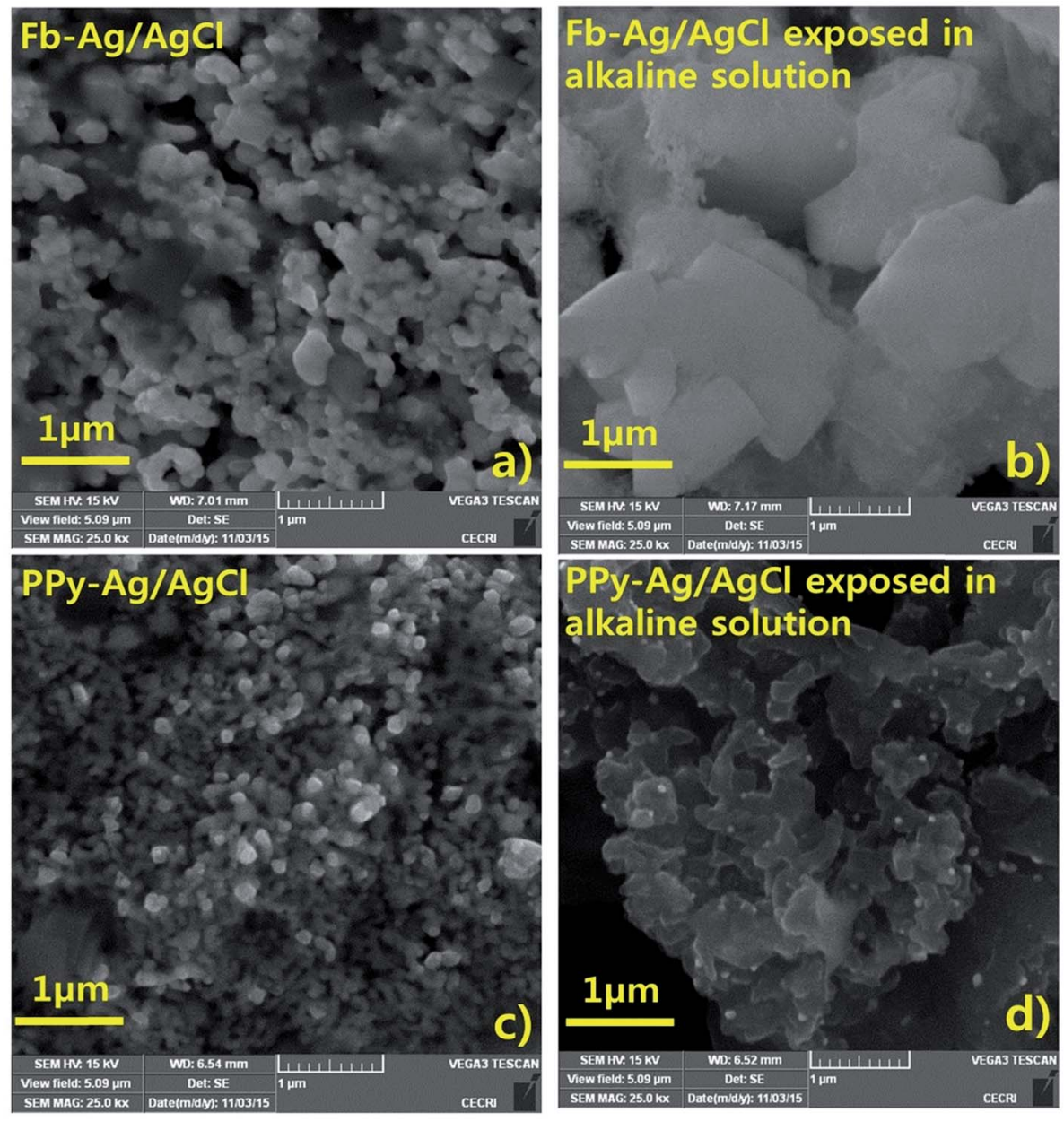

Fig. 10 SEM images for Fb-Ag/AgCl electrode before (a), after (b) and PPy-Ag/AgCl electrodes before (c), after (d) immersion in SCPS. 


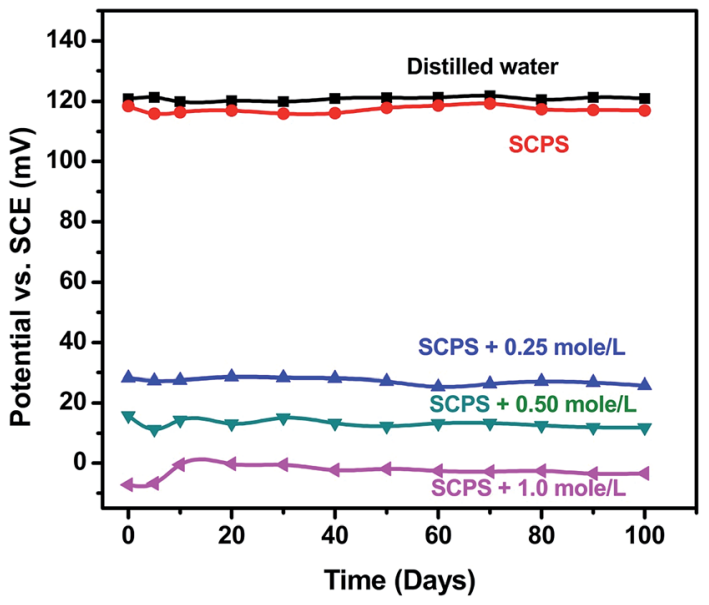

Fig. 11 Half-cell potential for PPy-Ag/AgCl electrode in distilled water and various chloride concentrations of SCPS.

electrode potential in SCPS for the exposure period of 60 days (Fig. 6). This result also confirmed that the PPy coating prevents $\mathrm{AgCl}$ from the formation of $\mathrm{Ag}_{2} \mathrm{O}$. Therefore, the PPy coated $\mathrm{Ag} /$ $\mathrm{AgCl}$ electrodes are suitable for use as embeddable chloride sensors in concrete structure.

Fig. 10 shows the SEM images of the $\mathrm{Fb}-\mathrm{Ag} / \mathrm{AgCl}$ and $\mathrm{PPy}-\mathrm{Ag} /$ $\mathrm{AgCl}$ electrodes before and after exposure in an alkaline solution for 60 days. Fig. 10a and c show the SEM images of the Fb-Ag/ $\mathrm{AgCl}$ and $\mathrm{PPy}-\mathrm{Ag} / \mathrm{AgCl}$ electrodes, respectively, before immersion in SCPS. Fig. 10a and c show the $\mathrm{Fb}-\mathrm{Ag} / \mathrm{AgCl}$ and $\mathrm{PPy}-\mathrm{Ag} / \mathrm{AgCl}$ electrodes in which the surface morphology is not much affected in both the images. The SEM image shown in Fig. 10b clearly indicates the reactions occurring on the $\mathrm{Fb}-\mathrm{Ag} / \mathrm{AgCl}$ surface (i.e. formation of $\mathrm{Ag}_{2} \mathrm{O}$ ) when the $\mathrm{Fb}-\mathrm{Ag} / \mathrm{AgCl}$ electrode is exposed to SCPS. Comparing the images Fig. 10a and b, a bigger particle size crystal growth formation of $\mathrm{Ag}_{2} \mathrm{O}$ is clearly visible in Fig. 10b, but it is well evidenced from Fig. 10d that there is no formation of crystal growth when the $\mathrm{PPy}-\mathrm{Ag} / \mathrm{AgCl}$ electrode is exposed to SCPS.

Therefore, the alkaline stable $\mathrm{PPy}-\mathrm{Ag} / \mathrm{AgCl}$ electrodes are suitable for use as embeddable chloride sensors in a concrete environment. Hence, further calibration and chloride sensing tests were carried out with the $\mathrm{PPy}-\mathrm{Ag} / \mathrm{AgCl}$ electrode only.

\subsection{Stability of PPy coated $\mathrm{Ag} / \mathrm{AgCl}$ electrode in various test solutions}

Fig. 11 shows the potentiometric response of the $\mathrm{PPy}-\mathrm{Ag} / \mathrm{AgCl}$ electrode in different test solutions such as distilled water, chloride-free synthetic concrete pore solution (SCPS) and chloride-contaminated synthetic concrete pore solution. The PPy$\mathrm{Ag} / \mathrm{AgCl}$ electrode showed stable average potential values of 121.0 $\pm 2 \mathrm{mV} v$ s. SCE in distilled water and $119.5 \pm 2 \mathrm{mV} v s$. SCE in SCPS. This potential difference between distilled water and SCPS was $1.5 \mathrm{mV} v s$. SCE. Furthermore, there was no significant change in the electrode potential of the $\mathrm{PPy}-\mathrm{Ag} / \mathrm{AgCl}$ electrode. Therefore, the PPy coating can prevent $\mathrm{OH}^{-}$ion interference when measuring the potential of the $\mathrm{PPy}-\mathrm{Ag} / \mathrm{AgCl}$ electrode in SCPS. Upon the addition of chloride ions (such as 0.25 mole per $\mathrm{L}, 0.50$
Table 3 Relationship between electrode potential and chloride concentration in concrete environment

\begin{tabular}{ll}
\hline $\begin{array}{l}\text { Potential range } \\
\text { (mV } v s . \mathrm{SCE})\end{array}$ & $\begin{array}{l}\text { Chloride concentration } \\
\text { (mole per } \mathrm{L}) \times 10^{-2}\end{array}$ \\
\hline$\geq 120 \pm 10 \mathrm{mV}$ & 0 to 0.14 \\
100 to $95 \mathrm{mV}$ & 0.28 to 0.56 \\
95 to $90 \mathrm{mV}$ & 0.56 to 1.12 \\
90 to $85 \mathrm{mV}$ & 1.12 to 1.68 \\
85 to $80 \mathrm{mV}$ & 1.68 to 2.25 \\
80 to $75 \mathrm{mV}$ & 2.25 to 2.81 \\
75 to $60 \mathrm{mV}$ & 2.81 to 5.6 \\
60 to $45 \mathrm{mV}$ & 5.6 to 14.0 \\
45 to $25 \mathrm{mV}$ & 14.0 to 25.0 \\
25 to $10 \mathrm{mV}$ & 25.0 to 50.0 \\
10 to $-10 \mathrm{mV}$ & 50.0 to 1.0 \\
Below $-10 \mathrm{mV}$ & Above 1.0 \\
&
\end{tabular}

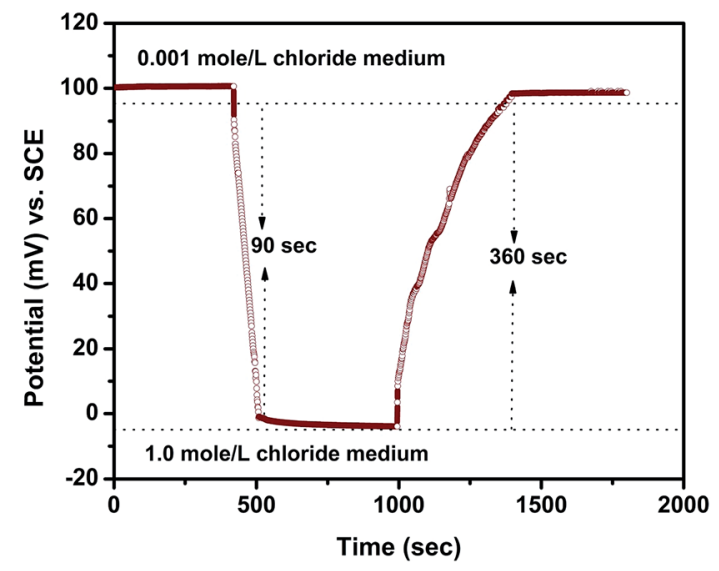

Fig. 12 Response time behavior of the $\mathrm{PPy}-\mathrm{Ag} / \mathrm{AgCl}$ electrode in low and high concentrations of chloride.

mole per $\mathrm{L}$ and 1.0 mole per $\mathrm{L}$ ) in SCPS, the measured potential values were $28.3 \pm 2 \mathrm{mV}, 12.3 \pm 2 \mathrm{mV}$ and $-3.3 \pm 2 \mathrm{mV}$, respectively. The relation between electrode potential and chloride concentration is given in Table 3. As noted earlier, the potential values decrease with increasing chloride ion concentration. This direct relationship enables us to use the $\mathrm{PPy}-\mathrm{Ag} / \mathrm{AgCl}$ electrode for chloride sensing application in concrete structures.

Since the PPy-Ag/AgCl electrode exhibits excellent stability and reversibility in SCPS and different chloride concentration solutions, its response times with low and high concentration of chloride are essential to validate the chloride ion sensing ability.

The response time graph of the $\mathrm{PPy}-\mathrm{Ag} / \mathrm{AgCl}$ electrode at 0.001 mole per $\mathrm{L}$ and 1.0 mole per $\mathrm{L}$ is given in Fig. 12. It was observed from Fig. 12 that the time taken to reach a steady potential value from 0.001 mole per $\mathrm{L}$ to 1.0 mole per $\mathrm{L}$ chloride was 90 seconds; it is interesting to note that the rapid response may be due to the high chloride ion concentration and the presence of hydrophilic quaternary $\mathrm{PPy}^{48}$ for quick interaction with chloride ions. The time taken to reach a steady potential value is 360 seconds for the reverse $(1.0$ mole per $L$ to 0.001 mole per L) measurement. These results indicate that the 


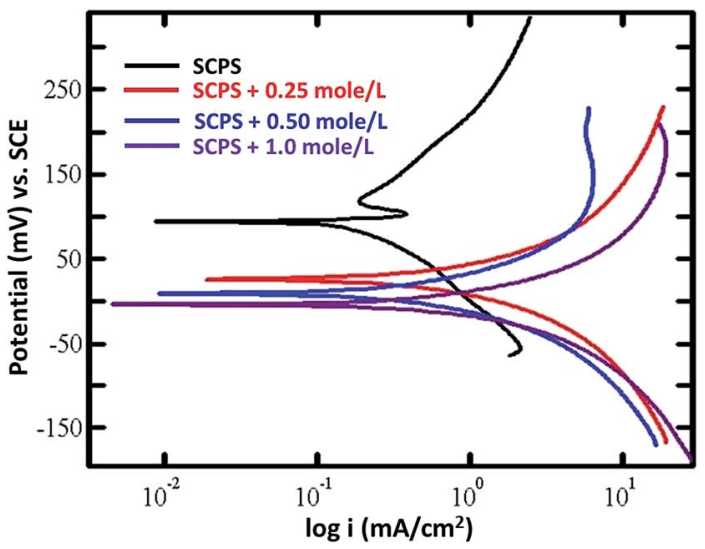

Fig. 13 Potentiodynamic polarization curves for the $\mathrm{PPy}-\mathrm{Ag} / \mathrm{AgCl}$ electrode in SCPS with various chloride concentrations.

concentration of chloride ions was very low when compared to $\mathrm{OH}^{-}$ions and the internal $\mathrm{OH}^{-}$ions accelerated the recovery time but they do not influence the chloride sensing properties.

\subsection{Electrochemical behaviours of $\mathrm{PPy}-\mathrm{Ag} / \mathrm{AgCl}$ electrode}

Fig. 13 shows the potentiodynamic polarization of the PPy-Ag/ $\mathrm{AgCl}$ electrode in SCPS with different chloride concentrations. The corresponding corrosion kinetic parameters are given in Table 4. The $E_{\text {corr }}$ value of the $\mathrm{PPy}-\mathrm{Ag} / \mathrm{AgCl}$ electrode was $103 \mathrm{mV} v s$. SCE in SCPS. In the presence of 0.25 mole per L, 0.50 mole per $\mathrm{L}$ and 1.0 mole per $\mathrm{L}$ of chloride, the $E_{\text {corr }}$ values of the electrode were $26.08,11.63$ and $-2.8 \mathrm{mV}$ ( $v s$. SCE), respectively. The corrosion current density of the PPy coated $\mathrm{Ag} / \mathrm{AgCl}$ electrode was $0.1529 \mathrm{~mA} \mathrm{~cm}^{-2}$ in SCPS. Upon the addition of 0.25 mole per L, 0.50 mole per $\mathrm{L}$ and 1.0 mole per $\mathrm{L}$ of chloride, the


respectively. The addition of chloride in SCPS increased the corrosion current density of the $\mathrm{PPy}-\mathrm{Ag} / \mathrm{AgCl}$ electrode.

Fig. 14 shows the Nyquist curves for the PPy-Ag/AgCl electrode in SCPS containing chloride ion concentrations of 0.25 mole per L, 0.50 mole per $\mathrm{L}$ and 1.0 mole per $\mathrm{L}$. The impedance parameters are given in Table 5 . The $R_{\mathrm{ct}}$ value of the $\mathrm{PPy}-\mathrm{Ag} /$ $\mathrm{AgCl}$ electrode was $11.81 \Omega \mathrm{cm}^{2}$. The $R_{\mathrm{ct}}$ values noted were 9.152, 2.266 and $2.162 \Omega \mathrm{cm}^{2}$ in the presence of chloride at 0.25 mole per L, 0.50 mole per $\mathrm{L}$ and 1.0 mole per L, respectively. It was also observed that the increase in chloride ion concentration decreases the charge transfer resistance $\left(R_{\mathrm{ct}}\right)$ of the $\mathrm{PPy}-\mathrm{Ag} /$ $\mathrm{AgCl}$ electrode. The $C_{\mathrm{dl}}$ value of the PPy coated $\mathrm{Ag} / \mathrm{AgCl}$ electrode was $0.4033 \times 10^{-1} \mathrm{~F} \mathrm{~cm}^{-2}$. In the presence of 0.25 mole per $\mathrm{L}, 0.50$ mole per $\mathrm{L}$ and 1.0 mole per $\mathrm{L}$ of chloride, the $C_{\mathrm{dl}}$

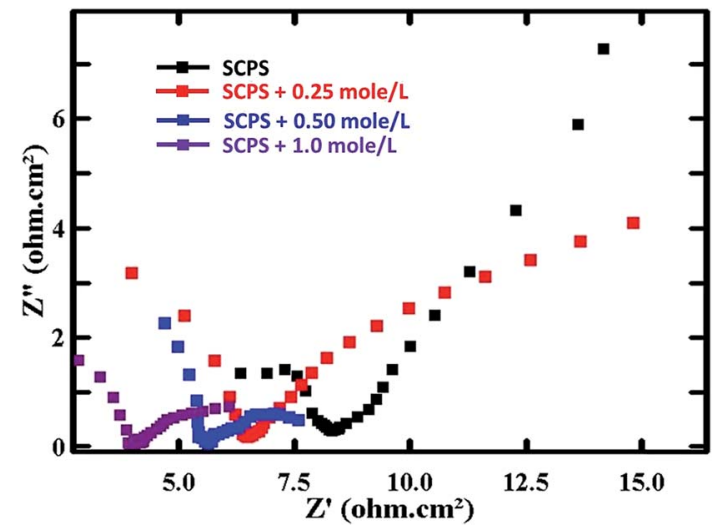

Fig. 14 AC-impedance curves for the PPy coated $\mathrm{Ag} / \mathrm{AgCl}$ electrode in SCPS with various chloride concentrations.

values observed are $0.58163 \times 10^{-1}, \quad 1.6560 \times 10^{-1}$ and $1.7410 \times 10^{-1} \mathrm{~F} \mathrm{~cm}^{-2}$, respectively.

\subsection{Standardization of $\mathrm{PPy}-\mathrm{Ag} / \mathrm{AgCl}$ electrode with respect to $\mathrm{MnO}_{2}$}

The PPy-Ag/AgCl electrode was calibrated with an $\mathrm{MnO}_{2}$ electrode. The fabrication of the $\mathrm{MnO}_{2}$ solid state reference electrode (SSRE) was discussed elsewhere. ${ }^{49}$ The stable potential value of the $\mathrm{MnO}_{2}$ electrode was $+206 \pm 6 \mathrm{mV}$ in SCPS and chloride contaminated SCPS. ${ }^{50}$ The potential of the $\mathrm{PPy}-\mathrm{Ag} / \mathrm{AgCl}$ electrode with respect to $\mathrm{MnO}_{2}$ in SCPS containing low chloride concentrations ranging from 0.001 to 0.01 mole per $\mathrm{L}$ was measured and is plotted in Fig. 15a. The figure shows that there was a significant change in the potential observed with the increasing chloride ion concentration in SCPS. Further, the measured potential decreases from $-106 \mathrm{mV}$ to $-153 \mathrm{mV}$ with increasing chloride ion concentration ranging from 0.001 to 0.01 mole per L in SCPS. In addition, the potential vs. high chloride ion concentration ranging from 0.01 to 1.0 mole per $\mathrm{L}$ is shown in Fig. 15b. Here also, the potential values decrease from $-174 \mathrm{mV}$ to $-213 \mathrm{mV}$ with increasing chloride ion concentrations ranging from 0.01 to 1.0 mole per L.

The $\mathrm{PPy}-\mathrm{Ag} / \mathrm{AgCl}$ electrode has a good linear relationship between the potential and the logarithmic chloride ions activity is termed as the Nernstian equation. Furthermore, the correlation coefficient $R^{2}$ values are 0.98 and 0.99 at low (0.001 to 0.01 mole per $\mathrm{L}$ ) and high ( 0.01 to 1.0 mole per $\mathrm{L}$ ) concentrations of chloride ions in SCPS, respectively. However, a slight deviation $\left(R^{2}=0.98\right)$ from linearity is observed at low chloride ion concentrations when compared with high chloride ion concentrations. The slight deviation of potential is due to the

Table 4 Potentiodynamic polarization parameters for the PPy-Ag/AgCl electrode in SCPS with various chloride concentrations

\begin{tabular}{|c|c|c|c|c|c|}
\hline $\begin{array}{l}\text { Concentration } \\
\text { of } \mathrm{Cl}^{-} \text {(mole per L) }\end{array}$ & $R_{\mathrm{p}}(\mathrm{mV})$ & $E_{\text {corr }}(\mathrm{mV})$ & $b_{\mathrm{a}}\left(\mathrm{mV} \mathrm{dec}{ }^{-1}\right)$ & $b_{\mathrm{c}}\left(\mathrm{mV} \mathrm{dec}^{-1}\right)$ & $I_{\text {corr }}\left(\mathrm{mA} \mathrm{cm}^{-2}\right)$ \\
\hline 0 & 124 & 103 & 55 & 104 & 0.1529 \\
\hline 0.25 & 32 & 26.8 & 38 & 38.4 & 0.3124 \\
\hline 0.50 & 20 & 11.63 & 51 & 55 & 0.4112 \\
\hline 1.0 & 10 & -2.82 & 51 & 47 & 0.6277 \\
\hline
\end{tabular}


Table 5 AC-impedance parameters for the PPy-Ag/AgCl electrode in SCPS with various chloride concentrations

\begin{tabular}{|c|c|c|c|c|}
\hline $\begin{array}{l}\text { SCPS containing various } \\
\mathrm{Cl}^{-} \text {concentrations (mole per } \mathrm{L} \text { ) }\end{array}$ & $I_{\text {corr }}\left(\mathrm{mA} \mathrm{cm}^{-2}\right)$ & $R_{\mathrm{S}}\left(\Omega \mathrm{cm}^{2}\right)$ & $R_{\mathrm{ct}}\left(\Omega \mathrm{cm}^{2}\right)$ & $C_{\mathrm{dl}}\left(\times 10^{-1} \mathrm{~F} \mathrm{~cm}^{-2}\right)$ \\
\hline 0 & 2.209 & 8.305 & 11.81 & 0.4033 \\
\hline 0.25 & 2.850 & 6.433 & 9.152 & 0.5816 \\
\hline 0.50 & 11.510 & 5.571 & 2.266 & 1.6560 \\
\hline 1.0 & 12.071 & 3.396 & 2.162 & 1.7410 \\
\hline
\end{tabular}
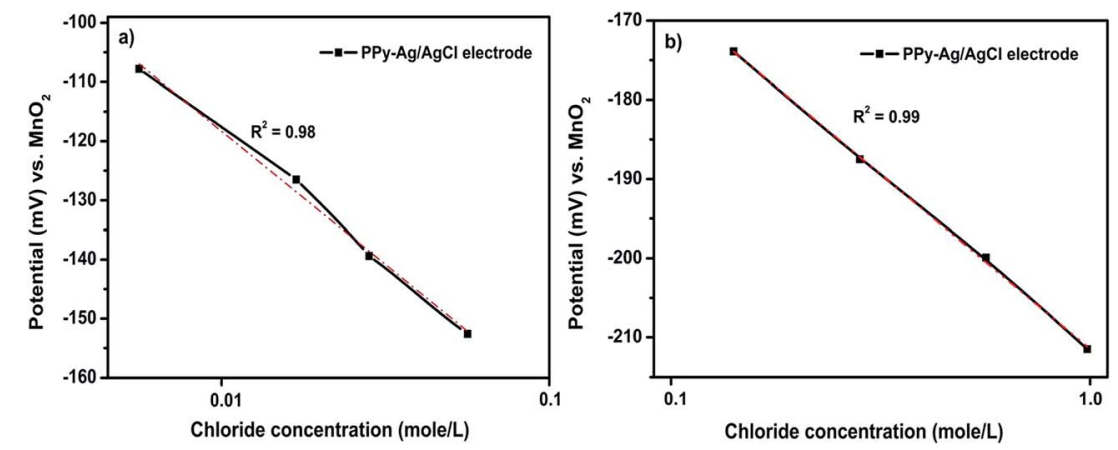

Fig. 15 Calibration of the PPy coated Ag/AgCl electrode with respect to $\mathrm{MnO}_{2}$ in SCPS containing low (a) and high (b) concentration of chloride solution.

$\mathrm{OH}^{-}$interference during the measurement. This minor deviation is considered as a negligible change. Hence, a straight line curve for the $\mathrm{PPy}-\mathrm{Ag} / \mathrm{AgCl}$ electrode was exhibited at all chloride ion concentrations in Fig. 15a and b. From this study, it is inferred that the $\mathrm{PPy}-\mathrm{Ag} / \mathrm{AgCl}$ electrode has a stable potential and is suitable for application in long-term chloride ion monitoring of civil infrastructures.

\subsection{Evaluation of PPy-Ag/AgCl electrode embedded in concrete}

Fig. 16 shows the chloride migration profile of the $\mathrm{PPy}-\mathrm{Ag} / \mathrm{AgCl}$ electrode embedded at 5, 10, 20, 30 and $40 \mathrm{~mm}$ depths of concrete. The potentials vary with increasing depth. The impact of the free $\mathrm{Cl}^{-}$ions concentration at lower depth $(5$ and $10 \mathrm{~mm})$

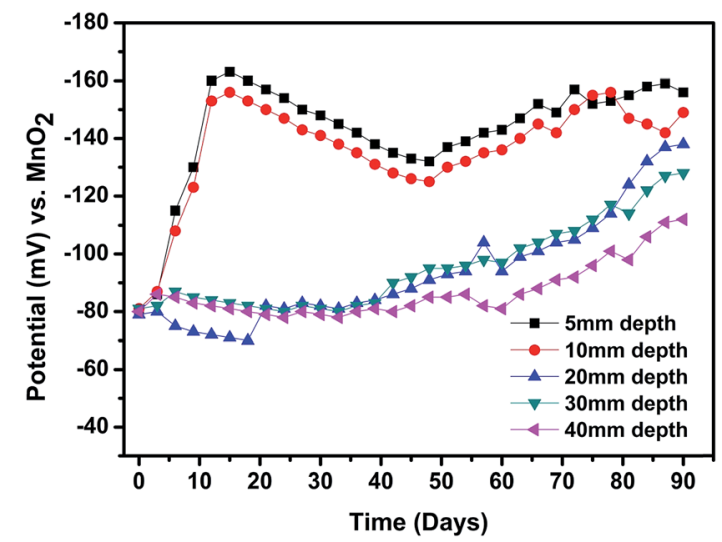

Fig. 16 Potential (against $\mathrm{MnO}_{2}$ ) vs. time behavior of the PPy coated $\mathrm{Ag} / \mathrm{AgCl}$ electrode exposed at various depths. is greater than at the higher depth of concrete $(20 \mathrm{~mm}$ to 40 $\mathrm{mm}$ ). This is because initially the concrete is dry and porous in nature, which allows more chloride ions to penetrate through the pores of the concrete. The chloride penetration at 5 and 10 $\mathrm{mm}$ depth is rapid during the first 5 days, showing the increase in potential, and after that the potential decreases; after $17^{\text {th }}$ day the potential increases again and it reached the maximum at the $30^{\text {th }}$ day. The decrease in potential may be owing to the complexation of chlorides with the cement hydration products, leading to the formation of Friedel's salt, ${ }^{51}$ which caused a decrease in the free chloride content.

\section{Conclusions}

The following conclusions were drawn from the above study:

- A solid state alkaline chloride electrode was prepared and fabricated for chloride sensing application in concrete infrastructure.

- The presence of the conducting polymer prevented the formation of $\mathrm{Ag}_{2} \mathrm{O}$ in the $\mathrm{PPy}-\mathrm{Ag} / \mathrm{AgCl}$ electrode, which is comparable with the $\mathrm{Fb}-\mathrm{Ag} / \mathrm{AgCl}$ electrode and has good alkaline stability.

- In addition to alkaline stability, the chloride sensing capability of PPy-Ag/AgCl electrode was confirmed by HCP and polarization studies. It illustrates that the PPy coating did not affect the electrochemical behavior of the $\mathrm{Ag} / \mathrm{AgCl}$ electrode.

- The PPy-Ag/AgCl electrode possesses a rapid, reversible characterization in chloride solution. For example, from 0.001 to 1.0 mole per $\mathrm{L}$ of chloride the time taken to reach the steady state potential is $90 \mathrm{~s}$, and the same is 360 seconds for the 
reverse measurements (from high concentration to low concentration of chloride ions).

- The HCP of the PPy-Ag/AgCl electrode was $120 \mathrm{mV} v s$. SCE. The electrode clearly distinguished the difference in chloride ion concentrations ranging from 0.001 to 1.0 mole per $\mathrm{L}$ per ppm and thereby the electrode has an excellent chloride sensing ability.

- Further calibration of the $\mathrm{PPy}-\mathrm{Ag} / \mathrm{AgCl}$ electrode was evaluated with respect to $\mathrm{MnO}_{2}$ under various depths in chloride contaminated concrete and the results showed that the PPy coated electrode has excellent chloride sensing ability.

- The data collected from the above tests reveal that the fabricated electrode is more stable in an alkaline medium and can be used as a chloride monitoring sensor in civil infrastructures.

\section{Acknowledgements}

This research was supported by the Basic Science Research Program through the National Research Foundation of Korea (NRF) funded by the Ministry of Science, ICT, \& Future Planning (No. 2015R1A5A1037548).

\section{References}

1 P. Castro, E. I. Moreno and J. Genesca, Cem. Concr. Res., 2000, 30, 1565-1571.

2 T. U. Mohammed, H. Hamada and T. Yamaji, ACI Mater. J., 2004, 101, 13-18.

3 M. Moradian, M. Shekarchi, M. Aabdollah and R. Alidadi, J. Perform. Constr. Facil., 2012, 26, 633-643.

4 H. Zhao, Y. M. Zhang and J. Ming, Hydrogen Sci. Eng., 2013, 5, 54-60.

5 Y. D. Song, J. H. Liu, F. X. Yi, B. Xu and P. Ge, Appl. Mech. Mater., 2013, 345, 184-188.

6 L. Bertolini, B. Elsener, P. Pedeferri and R. Polder, Corrosion of Steel in Concrete: Prevention, Diagnosis, Repairs, Wiley-VCH, 2nd edn, 2013, vol. 91-104, DOI: 10.1002/3527603379.

7 G. K. Glass and N. R. Buenfeld, Progr. Struct. Eng. Mater., 2000, 2, 448-458.

8 X. Shi, N. Xie and K. Fortune, Constr. Build. Mater., 2012, 30, 125-138.

9 C. Arya, N. R. Buenfield and J. B. Newman, Cem. Concr. Res., 1987, 17, 907-918.

10 C. P. Atkins, M. A. Carter and J. D. Scantlebury, Cem. Concr. Res., 2001, 31, 1207-1211.

11 U. Angst, B. Elsener, C. K. Larsen and O. Vennesland, J. Appl. Electrochem., 2010, 40, 561-573.

12 Y. Abbas, W. Olthuis and A. van den Berg, Sens. Actuators, B, 2013, 188, 433-439.

13 W. McCarter, T. Chrisp, G. Starrs, A. Adamson, E. Owens, P. A. M. Basheer, S. V. Nanukuttan, S. Srinivasan and N. Holmes, J. Infrastruct. Syst., 2012, 18, 167-175.

14 M. Torres-Luque, E. Bastidas-Arteaga, F. Schoefs, M. Sanchez -Silva and J. F. Osma, Constr. Build. Mater., 2014, 68, 68-81.

15 B. Elsener, L. Zimmermann and H. Bohni, Mater. Corros., 2003, 54, 440-446.
16 K. N. Gurusami, M. P. Geoghegan, in Corrosion of Reinforcement in concrete, ed. C. L. Page, K. W. J. Treadaway and P. B. Bamforth, Society of Chemical Industry, London, 1990, pp. 333-347.

17 X. Gao, J. Zhang, Y. Yang and H. Deng, Sensors, 2010, 10, 10226-10239.

18 M. A. Climent-Lorca, E. Viqueira-Perez and M. M. LopezAtalaya, Cem. Concr. Res., 1996, 26, 1157-1161.

19 C. P. Atkins, J. Scantlebury, P. Nedwell and S. Blatch, Cem. Concr. Res., 1996, 26, 319-324.

20 U. Angst, B. Elsener, C. K. Larsen and O. Vennesland, J. Appl. Electrochem., 2010, 40, 561-573.

21 G. Duffo, S. Farina and C. Giordano, Electrochim. Acta, 2009, 54, 1010-1020.

22 G. De Vera, M. Climent, C. Antón, A. Hidalgo and C. Andrade, J. Electroanal. Chem., 2010, 639, 43-49.

23 F. Pargar, D. A. Koleva, O. Copuroglu, E. A. B. Koenders and K. van Breugel, Constr. Mater., 2014, uuid:95faa6e6-bfa94f7b-8e25-de4a55c2493a.

24 J. Junsomboon and J. Jakmunee, Talanta, 2008, 76, 365-368. 25 M. F. Montemor, J. H. Alves, A. M. Simoes, J. C. S. Fernandes, Z. Lourenço, A. J. S. Costa, A. J. Appleton and M. G. S. Ferreira, Cem. Concr. Compos., 2006, 28, 233-236.

26 R. G. Du, R. G. Hu, R. S. Huang and C. J. Lin, Anal. Chem., 2006, 78, 3179-3185.

27 Y. S. Femenias, U. Angst, F. Caruso and B. Elsener, Mater. Struct., 2016, 49, 2637-2651.

28 T. Blaz, J. Migdalski and A. Lewenstam, Analyst, 2005, 130, 637-643.

29 J. Ha, S. M. Martin, Y. Jeon, I. J. Yoon, R. B. Brown, H. Nam and G. S. Cha, Anal. Chim. Acta, 2005, 549, 59-66.

30 A. Talaie, J. Y. Lee, Y. K. Lee, J. Jang, J. A. Romagnoli, T. Taguchi and E. Maeder, Thin Solid Films, 2000, 363, 163-166.

31 N. M. Rowley and R. J. Mortimer, Sci. Prog., 2002, 85, 243262.

32 N. L. Pickup, M. Lam, D. Milojevic, R. Y. Bi, J. S. Shapiro and D. K. Y. Wong, Polymer, 1997, 38, 2561-2565.

33 K. M. Mangold, S. Schafer and K. Juttner, Fresenius. J. Anal. Chem., 2000, 367, 340-342.

34 R. N. Singh Madhu and R. Awasthi, Polypyrrole Composites: Electrochemical Synthesis, Characterizations and Applications, Electropolymerization, ed. Ewa Schab-Balcerzak, In Tech, 2011, ISBN: 978-953-307-693-5, http://www.intechopen.com/books/ electropolymerization/polypyrrolecomposites-electrochemicalsynthesis-characterizations-and-applications.

35 J. Pionteck, M. Omastova, P. Potschke, F. Simon and I. Chodak, J. Macromol. Sci., Part B: Phys., 1999, 38, 737-748.

36 Q. Hao, V. Kulikov and V. M. Mirsky, Sens. Actuators, B, 2003, 94, 352-357.

37 S. N. Eliseeva, V. V. Maleva and V. V. Kondrat, Russ. J. Electrochem., 2009, 45, 1045-1051.

38 V. Tsakova, J. Solid State Electrochem., 2008, 12, 1421-1434. 39 J. Vatsalarani, S. Geetha, D. C. Trivedi and P. C. Warrier, J. Power Sources, 2006, 158, 1484-1489.

40 G. Bidan, Sens. Actuators, B, 1992, 6, 45-56. 
41 N. Gomez and C. E. Schmidt, J. Biomed. Mater. Res., Part A, 2007, 81, 135-149.

42 M. J. Swann, D. Bloor, T. Haruyama and M. Aizawa, Biosens. Bioelectron., 1997, 12, 1169-1182.

43 J. Stejskal, M. Trchova, P. Bober, Z. Moravkov, D. S. Kopecky, M. Vrnata, J. Proke, M. Varga and E. Watzlova, RSC Adv., 2016, 6, 88382-88391.

44 X. Zhang, S. Stewart, D. W. Shoesmith and J. C. Wren, J. Electrochem. Soc., 2007, 154, 70-76.

45 M. E. Poisot-Diaz, I. Gonzalez and G. T. Lapidus, Hydrometallurgy, 2008, 93, 23-29.

46 C. S. Yang, D. S. Shang, Y. S. Chai, L. Q. Yan, B. G. Shen and Y. sun, Phys. Chem. Chem. Phys., 2016, 18, 12466-12475.
47 R. G. Du, R. G. Hu, R. S. Huang and C. J. Lin, Anal. Chem., 2006, 78, 3179-3185.

48 W. Zhong, S. Liu, X. Chen, Y. Wang and W. Yang, Macromolecules, 2006, 39, 3224-3230.

49 S. P. Karthick, S. Muralidharan, V. Saraswathy and K. Thangavel, Sens. Actuators, B, 2014, 192, 303-309.

50 S. Muralidharan, V. Saraswathy, A. Madhavamayandi, K. Thangavel and N. Palaniswamy, Electrochim. Acta, 2008, 53, 7248-7254.

51 S. P. Karthick, S. Muralidharan, V. Saraswathy and S. J. Kwon, Journal of Structural Integrity and Maintenance, 2016, 1, 35-42. 